\title{
Bovine Trypanosomosis: Infection Rate, its Risk Factors, and the Relationship between Packed Cell Volume and Infection Rate in Humbo District, Southern Ethiopia
}

\author{
Ephrem Takele*, Kokeb Kore, Yohannes Geremew \\ National Institute for Control and Eradication of Tsetse fly and Trypanosomosis, Arbaminch Center, \\ Arbaminch, Ethiopia
}

*Corresponding Author: Ephrem Takele, National Institute for Control and Eradication of Tsetse fly and Trypanosomosis, Arbaminch Center, Arbaminch, Ethiopia, Email: ephremtakele58@gmail.com

\begin{abstract}
Background: Tsetse transmitted animal trypanosomosis still remains as one of the largest causes of livestock production losses in Ethiopia. The study was conducted from April, 2018 to June, 2018 in Humbo district of southern Ethiopia to determine current infection rate of bovine trypanosomosis, to identify trypanosome species responsible for infection, to assess potential risk factors of the disease, and to evaluate the relationship between infection rate and packed cell volume. Blood samples were collected from 306 randomly selected cattle from the study peasant associations (PAs) and evaluated through conventional parasitological methods.
\end{abstract}

Results: The overall trypanosomosis infection rate during the study period was $13.4 \%$ (95\% CI 9.8-17.7). The prevailing trypanosome species in the area were T. congolense and T. vivax with predominance of $T$. congolense (90.24\%). The areal distribution of trypanosomosis infection was found to be 4.8\%, 0\%, 18.9\%, $20 \%$ and $21.6 \%$ in Mareka, Gafata, Chokare, Bisare and Gurucho peasant associations (PAs) respectively. There was a significant variation in infection rate among different PAs, age groups and body condition scores $(p<0.05)$. That is the odds of trypanosomosis infection was significantly higher $(p=0.009, O R=$ 5.44, 95\% CI = 1.52-19.46) in Gurucho PA than Maraka, Gafata, Chokare, and Bisare PAs. Similarly, the odds of trypanosomosis infection was significantly higher $(p=0.001, O R=4.47,95 \% C I=1.78-11.25)$ in animals with poor body condition score $(24.5 \%)$ than in animals with medium body condition (15.8\%) and good body condition scores (6.7\%). Moreover, the odds of trypanosomosis infection was significantly lower $(p=0.039, O R=0.47,95 \% C I=0.23-0.96)$ in young animals than the older ones. Trypanosomosis infection rate was higher in male animals $(14.4 \%)$ than female animals $(12.7 \%)$ with no significant variation between the sexes $(p>0.05)$. The mean PCV of infected animals $(14.4 \pm 4 S D)$ was significantly $(P<0.05)$ lower than non-infected animals (20.17\% \pm 4.67 SD). One-way ANOVA analysis for comparison of mean PCV among the three categories (negative, T. Congolese positive and T. vivax positive) revealed highly significant association ( $p=0.000, F=20.37$ ) among the categories. Moreover, the Bonferoni multiple comparison test revealed the existence of significant mean PCV variation between negative category and T. congolense positive category $(p=0.000)$ as well as between negative category and T. vivax positive category $(p=0.039)$. However, the mean PCV variation between T. congolense positive category and T. vivax positive category was non-significant $(p>0.05)$. Out of 306 examined cattle, 257 were anaemic with $P C V<25 \%$ and the overall anaemia prevalence was $83.98 \%$ (95\% CI 79.85-88.11). The prevalence of anaemia in parasitaemic animals $(100 \%)$ was significantly $(p<0.05)$ higher compared to the aparasitaemic ones $(81.5 \%)$.

Conclusion: Bovine trypanosomosis is a major disease that remains to be a potential threat to cattle production in Humbo district. Hence, appropriate disease prevention and control methods should be implemented to improve cattle production in the area.

Keywords: Trypanosomosis, Humbo, cattle, infection rate, PCV

Abbreviations: $A N O V A=$ Analysis of Variance, masl $=$ meters above sea level, $P A s=$ Peasant Associations, PCV $=$ Packed Cell volume, $S D=$ Standard Deviation, $S E=$ Standard Error, BCS = Body Score; $C I=$ Confidence Interval; OR = Odds Ratio

\section{INTRODUCTION}

Trypanosomosis is a parasitic disease caused by unicellular protozoan parasites of the genus trypanosome and family trpanosomatidae they multiply in blood stream, lymphatic vessels and tissue, including cardiac muscle and the central 
nervous system (Souls by, 1992). Trypanosomosis is transmitted by tsetse flies (Glossinaspp) and believed to be the most important infectious disease holding back development of livestock production in Africa (Itard, 1981).

Trypanosomosis is one of the major constraints on animal production in areas of Africa which have the greatest potential for significant increases in domestic livestock productivity (D'Ieteren et al., 1998). Tsetse flies occur over some 10 million square kilometer of Africa (Jordan, 1986) affecting a total of 38 countries. Currently, about $37 \%$ of the 147 million cattle in countries affected by tsetse are exposed to the disease. Africa produces 70 times less animal protein per unit area than Europe (Nantulya, 1986). In Africa the overall loss (both direct and indirect) is estimated at US 500 billion dollars a year (ILRAD, 1993/94). Currently the livestock production and productivity of southern region is highly affected by the high incidence of the trypanosomosis. Ethiopia is believed to have the largest livestock population in Africa, which is currently estimated to be 54 million cattle, 25.5 million sheep and 24.1 million goats (CSA, 2013). However, about $240,000 \mathrm{~km}^{2}$ of arable land located in the Southern, South Western, Western and North Western parts is infested with tsetse flies (STEP, 2012) precludes farmers from rearing livestock. Morbidity and mortality losses from ruminant livestock alone are estimated to be USD 200 million (Abebe and Jobre, 1996). In Ethiopia above 14 million heads of cattle are exposed to the risk of trypanosomosis, 20,000 heads of which die every year. Taking 200 birr per animal, the total loss will be 4,000,000 birr per year (As faw, 1986). In the years 1978-1982 a total of 9,675,575 doses of trypanocidal drugs were purchased with 17,920,780.70 birr (MoA, 1982/3). Although tsetse flies have existed in Ethiopia for a very long time, it has been noted by early explorer, who lost their transport animals in the fly challenge belts. In 1885, Donald and Smith made the earliest record of Gendi (Nangana) in their transport animals which were crossing tsetse fly belts in southern Ethiopia (Maclennan, 1980). Later in 1895 Corti identified an insect collected in 1893 by Captain Bottogo, along the Walmal River which is the upper tributary of Shebelle River (Lang ridge, 1976). In 1962, the cattle survey in Southern Ethiopia by the livestock division, established that bovine trypanosomosis had become a major cattle disease in the Omo valley. It was stated that the problem of trypanosomosis is the main cause of decline in the number of cattle and particularly draught oxen (Abebe and Jobere, 1996). The most important trypanosomes in terms of economic loss in domestic livestock are the tsetse transmitted species: $T$. congolense, $T$. vivax and T.b. brucei (Getachew, 2005). Report from the tsetse infested area of Ethiopia indicated that $T$. congolense is the most prevalent trypanosome species (Abebe and Jobre, 1996; Rowland et al., 1993).

Currently the livestock production and productivity of southern region is highly affected by the high incidence of trypanosomosis. Therefore, taking in to account the above-mentioned statements, the following objectives were designed to conduct the study:

- To determine the prevalence of bovine trypanosomosis on the basis of area, age, sex, and body condition score of the animals.

- To determine the prevailing trypanosome species affecting cattle in the study area.

- To evaluate the relationship between trypanosomosis infection rate and packed cell volume

\section{Materials ANd Methods}

\subsection{Description of the Study Area}

The study was conducted in Humbo district which is one of the districts in the Southern Nations, Nationalities and Peoples region of Ethiopia. Humbo is bordered on the southeast by Lake Abaya which separates it from the Oromia Region, on the south by the Gamo Gofa Zone, on the west by Offa, on the northwest by Sodo Zuria, on the northeast by Damot Woyde, and on the east by the Bilate River which separates it from the Sidama Zone. Humbo is located $322 \mathrm{~km}$ south of the capital, Addis Ababa. According to zonal statistical data (2010), the total human population is 163705 ; and the total area of the woreda is $866.46 \mathrm{~km}^{2}$. Humbo woreda lies between $6^{0} 51^{\prime} 14 " \mathrm{~N}$ and $6^{0}$ $79^{\prime} 25^{\prime \prime} \mathrm{N}$ latitudes, and $37^{\circ} 59^{\prime} 41^{\prime \prime} \mathrm{E}$ and $38^{\circ}$ 05'54"E longitudes.

The altitude ranges from $1100 \mathrm{~m}$ to 2355 meters above sea level. Moreover, the altitude of lowlands varies from 1100 to 1600 meters above sea level. The area is sub divided into two agro ecological zones: lowland (kola) with an altitude below 1500m.a.s.l and midland (weina dega) 
with an altitude range of 1500-2355 meters above sea level. The mean annual temperature is $22^{\circ} \mathrm{C}$.The rainfall is erratic with an annual average rain fall of 843 to $1403 \mathrm{~mm}$. The vegetation of the study peasant associations
(PAs) is dominantly occupied by bush land and shrubs. The prevailing production system in the area is mixed crop and livestock production (WZSEP, 2010).

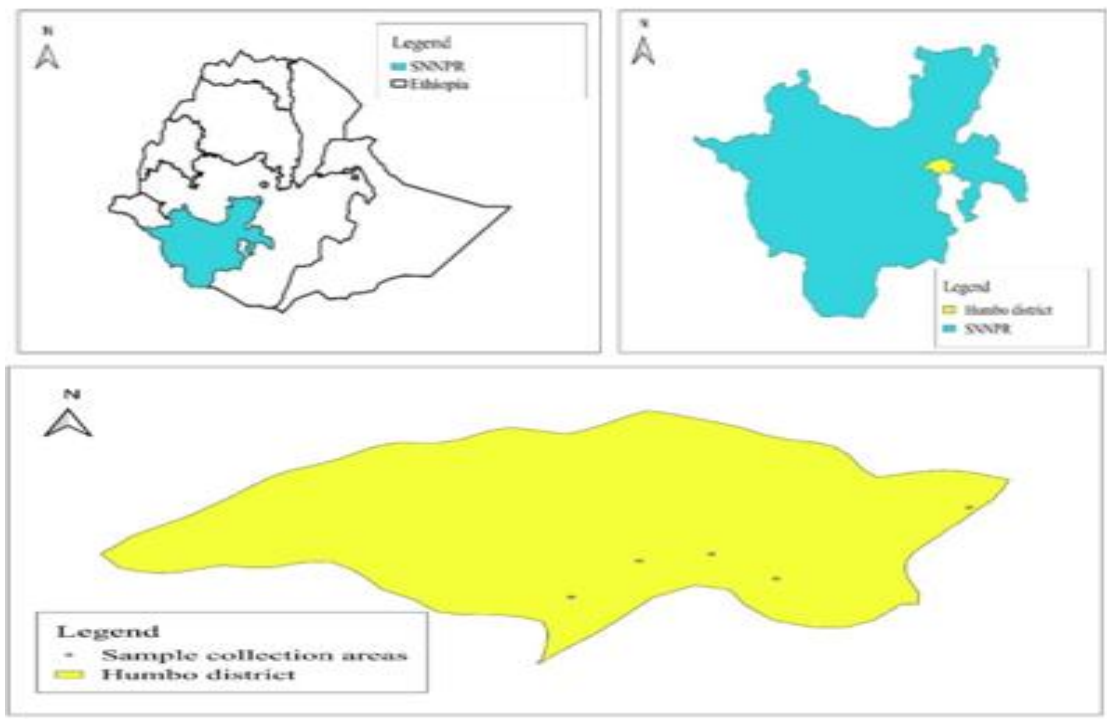

Figure1: Location map of the study area

\subsection{Study Population}

The survey was conducted in five peasant associations (PAs) of Humbo district namely, Mareka, Gafata, Chokare, Bisare, and Gurucho. The study population was comprised of 306 zebu cattle of different ages and both sexes owned by local farmers. The cattle were reared with the traditional extensive grazing system.

\subsection{Study Design}

A cross-sectional type of study is conducted from April, 2018 to June, 2018 in the selected PAs in which blood samples were collected to measure PCV and to examine the presence of motile trypanosome parasites. Additionally, the age, sex, body condition and PA data of every sample animal was collected at the time of sampling. The age was categorized into two groups: young ( $\leq 3$ years) and adult ( $>3$ years) whereas the body condition score was grouped into good, medium and poor based on the appearance of ribs and dorsal spines applied for zebu cattle (Nicholson and Butterworth, 1986).

\subsection{Sample Size and Sampling Method}

The five PAs (villages) were purposively selected due to higher tsetse challenge and animals from each PA were selected using systematic random sampling of animals caught at sample collection points. A 95\% confidence interval and 5\% desired absolute precision and expected prevalence of $14.2 \%$ from previous study (Feyisa et al., 2011) in the area were used to determine the sample size for this particular study. The sample size was determined using the following formula (Thrus field, 2005).

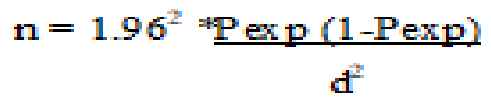

$\mathrm{n}=$ required sample size

Pexp $=$ expected prevalence $=14.2 \%$

$\mathrm{d}=$ desired absolute precision $=0.05$

Accordingly, the sample size was determined to be 187 . However, a total of 306 samples were collected due to availability of sample animals.

\subsection{Parasitological and Hematological Techniques}

The parasitological diagnostic tests used were those described by Paris et al., (1982). In brief, blood was collected from peripheral ear vein into heparin zed capillary tubes. Each capillary tube was filled to its last third and sealed with crystal seal at one end and centrifuged immediately in a micro hematocrit centrifuge for five minutes at 12000rpm. After centrifugation, the packed cell volume (PCV) was determined. Animal with PCV less than or equal to $24 \%$ were considered to be anaemic (Radostitis et al., 2007). After PCV determination, the capillary tube was cut using a diamond tipped pen $1 \mathrm{~mm}$ below the Buffy coat 
to include the upper most layers of the red blood cells. The extracted samples were placed on to microscopic slide, covered with cover slip and examined under phase contrast microscope with a 40x objective for the presence of motile trypanosomes.

\section{Data AnAlysis}

The collected raw data was fed into Microsoft excel spread sheets and analysis was done using STATA ${ }^{\circledR}$ (version 14.0) software program from STATA Corporation, College Station, Texas. Moreover, descriptive statistics like frequency and percentages were used to summarize the the results. The prevalence of trypanosome infection was calculated as the number of animals tested positive by Buffy coat method divided by the total number of animals examined at that particular time. The association between trypanosomosis infection status and different risk factors were assessed using unavailable binomial logistic regression and mean PCV values of parasitaemic and aparasitemic cattle were compared by using two Table1: Species prevalence of bovine trypanosomosis during the study period sample student t-tests. Likewise, one-way ANOVA analysis was employed to compare the mean PCV among the three categories (negative, T. congolense positive and T. vivax positive). Moreover, Bonferoni multiple comparison test was employed to identify the category with significant mean PCV variation among the three categories. Differences between parameters were tested for significance at probability level of $\mathrm{p}<0.05$ and $95 \%$ confidence interval.

\section{Results}

\subsection{Parasitological Findings and Risk Factors Analysis}

Out of 306 examined cattle, 41 were positive for trypanosomosis and the overall infection rate was $13.4 \%$ (95\% CI, 9.8-17.7). Out of the 41 positive animals, $37(90.24 \%)$ were found to be positive for $T$. congolense while $4(9.76 \%)$ were positive with T. vivax. This indicated that $90 \%$ of infection was caused by $T$. congolense while only $10 \%$ was by $T$. vivax (Table1).

\begin{tabular}{|l|c|c|}
\hline \multicolumn{1}{|c|}{ Trypanosome species } & No of positives & Species prevalence (\%) \\
\hline$T$. congolense & 37 & 90.24 \\
\hline$T$. vivax & 4 & 9.76 \\
\hline Total & 41 & $100 \%$ \\
\hline
\end{tabular}

The areal distribution of trypanosomosis infection was found to be $4.8 \%, 0 \%, 18.9 \%$, $20 \%$ and 21.6. \% in Mareka, Gafata, Chokare, Bisare and Gurucho PAs respectively.

Trypanosomosis infection rate differed significantly among different PAs $(\mathrm{p}<0.05)$. That is, the odds of trypanosomosis infection was significantly higher $(\mathrm{p}=0.009, \mathrm{OR}=5.44$, 95\% $\mathrm{CI}=1.52-19.46$ ) in Gurucho PA than Maraka, Gafata, Chokare, and Bisare PAs. Moreover, analysis of trypanosomosis infection rate among different body condition categories revealed $6.7 \%, 15.8 \%$ and $24.5 \%$ infection rate in good, medium and poor body conditioned animals respectively. There was a significant variation in trypanosomosis infection rate among different body condition categories; i.e.

Table2: Univariable logistic regression analysis of trypanosomosis infection rate based on hyphothesized risk factors.

\begin{tabular}{|l|l|l|l|l|l|l|l|}
\hline $\begin{array}{l}\text { Risk } \\
\text { factors }\end{array}$ & Category & $\begin{array}{l}\text { No } \\
\text { Examined }\end{array}$ & $\begin{array}{l}\text { No } \\
\text { Positive }\end{array}$ & $\begin{array}{l}\text { Infection } \\
\text { rate (\%) }\end{array}$ & 95\% CI & OR[95\% CI] & P value \\
\hline \multirow{3}{*}{ PA } & Maraka & 83 & 4 & 4.8 & $1.32-11.8$ & Reference & \\
\cline { 2 - 8 } & Gafata & 37 & 0 & 0 & $0.0-9.48$ & 1 & - \\
\cline { 2 - 8 } & Chokare & 74 & 14 & 18.9 & $9.78-28.05$ & $4.6[1.44-14.71]$ & 0.01 \\
\cline { 2 - 8 } & Bisare & 75 & 15 & 20 & $11.64-30.83$ & $4.94[1.56-15.64]$ & 0.007 \\
\cline { 2 - 8 } & Gurucho & 37 & 8 & 21.6 & $8.82-38.21$ & $5.44[1.52-19.46]$ & 0.009 \\
\hline
\end{tabular}
significantly higher $(\mathrm{p}=0.001, \mathrm{OR}=4.47,95 \%$ $\mathrm{CI}=1.78-11.25)$ in animals with poor body condition score than in animals with medium and good body condition scores Trypanosomosis infection rate of $8.8 \%$ and $17 \%$ was recorded in young ( $\leq 3$ years)and old animals (>3years)respectively with statistically significant variation between the age groups $(p<0.05)$; i.e. the odds of trypanosomosis infection was significantly lower $(\mathrm{p}=0.039$, OR $=0.47,95 \% \mathrm{CI}=0.23-0.96$ ) in young animals than the older ones. Higher trypanosomosis infection rate was observed in male animals (14.4\%) compared to female animals (12.7\%) with no significant difference between the sexes $(\mathrm{p}>0.05)($ Table2)

\footnotetext{
ARC Journal of Animal and Veterinary Sciences
} 
Bovine Trypanosomosis: Infection Rate, its Risk Factors, and the Relationship between Packed Cell Volume and Infection Rate in Humbo District, Southern Ethiopia

\begin{tabular}{|l|l|l|l|l|l|l|l|}
\hline \multirow{3}{*}{ Sex } & Male & 118 & 17 & 14.4 & $8.62-22.06$ & $0.64[0.31-1.33]$ & 0.24 \\
\cline { 2 - 7 } & Female & 188 & 24 & 12.7 & $8.35-18.4$ & & \\
\hline \multirow{3}{*}{ Age } & $\leq 3$ yrs & 136 & 12 & 8.8 & $4.64-14.9$ & $0.47[0.23-0.96]$ & 0.039 \\
\cline { 2 - 7 } & $\geq 3$ yrs & 170 & 29 & 17 & $11.73-23.6$ & & \\
\hline \multirow{3}{*}{ BCS } & Poor & 53 & 13 & 24.5 & $12.55-36.5$ & $4.47[1.78-11.25]$ & 0.001 \\
\cline { 2 - 7 } & Medium & 120 & 19 & 15.8 & $9.8-23.6$ & $2.59[1.12-5.97]$ & 0.025 \\
\cline { 2 - 6 } & Good & 133 & 9 & 6.7 & $3.14-12.4$ & Reference & \\
\hline
\end{tabular}

$B C S=$ Body Condition Score $; C I=$ Confidence Interval; $O R=$ Odds Ratio $; P A=$ Peasant Association

\subsection{Hematological Results}

Packed cell volume of parasitemic animals was in the range of $8-24 \%$, while in aparasitemic cattle the PCV was in the range of 6-30\% (Figure 2).The overall mean PCV of examined animals was $19.52 \pm 4.87 \mathrm{SD}$. All parasitaemic animals $(100 \%)$ had PCV < $25 \%$ which is below the normal range. The mean PCV of parasitemic animals is $14.4 \pm 4 \mathrm{SD}$ which is lower than the lower limit of normal PCV for cattle. The mean PCV for aparasitemicanimals, is $20.17 \pm 4.67 \mathrm{SD}$ which is also below normal PCV value range (Table3). There was a statistically significant difference in the mean PCV value between the infected and non-infected animals $(\mathrm{p}<0.05)$. Additionally, the mean PCV value of the three categories of examined animals (Negative, T. congolense positive and $\mathrm{T}$. vivaxpositive) was compared using one-way ANOVA analysis
(Table 4). Accordingly, one-way ANOVA analysis revealed a mean PCV of 20.17 $\pm 4.67 \mathrm{SD}$ for negative, $15.37 \pm 3.82 \mathrm{SD}$ for $\mathrm{T}$. congolense positive and 14.25 $\pm 6.13 \mathrm{SD}$ for $\mathrm{T}$. vivax positive with significant $(\mathrm{p}=0.000, \mathrm{~F}=20.37)$ difference in mean PCV values among the three categories. Likewise, the Bonferroni multiple comparison test was employed to identify the category with mean difference. Accordingly, the test indicated existence of significant difference in the mean PCV value between negative category and $\mathrm{T}$. congolense positive category $(\mathrm{p}=0.000)$ as well as negative category and $\mathrm{T}$. vivax positive category $(\mathrm{p}=0.033)$ (Table5). No significant difference in the mean PCV value between T.congolense positive category and T.vivax positive category was observed $(\mathrm{p}=1.000)$ (Table5).

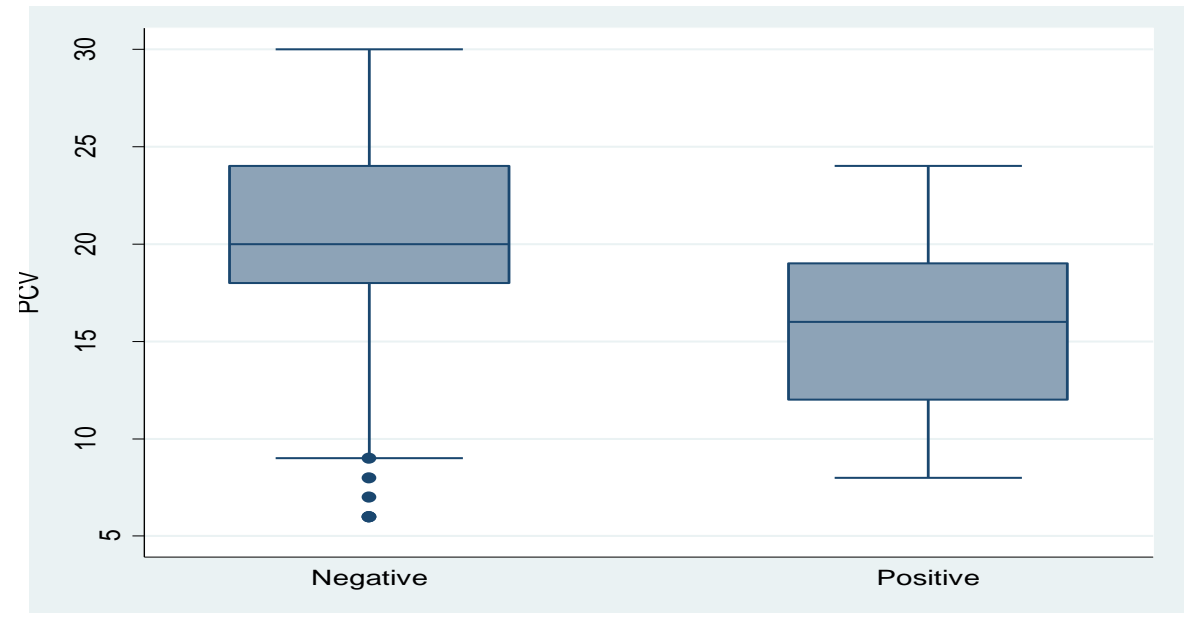

Figure2: Overall Mean PCV of aparsitaemic and parsitaemic animals

Table3: Mean PCV value for parasitaemic and aparasitaemic animals

\begin{tabular}{|l|l|l|l|l|l|l|}
\hline Infection status & Frequency & Mean PCV \pm SD & 95\% CI & SE & t-test & P value \\
\hline Aparasitaemic & 265 & $20.17 \pm 4.67$ & $19.61-20.74$ & 0.28 & 7.47 & 0.000 \\
\cline { 1 - 5 } Parasitaemic & 41 & $15.27 \pm 4.00$ & $14-16.53$ & 0.62 & & \\
\hline Overall & 306 & $19.52 \pm 4.87$ & $18.97-20.07$ & 0.278 & & \\
\hline
\end{tabular}

$P C V=$ Packed Cell Volume $; S D=$ Standard Deviation $; C I=$ Confidence Interval $;$ SE = Standard Error

Table4: One-way ANOVA analysis of mean PCV based on trypanosome infection and species.

\begin{tabular}{|l|c|c|c|c|c|}
\hline \multicolumn{1}{|c|}{ Infection Status } & Frequency & Mean PCV & SD & F & P value \\
\hline Negative & 265 & 20.17 & 4.67 & 27.85 & \multirow{2}{*}{0.000} \\
\cline { 1 - 4 } Positive for T. congolense & 37 & 15.37 & 3.82 & & \\
\hline Positive for T. vivax & 4 & 14.25 & 6.13 & & \\
\hline
\end{tabular}


Bovine Trypanosomosis: Infection Rate, its Risk Factors, and the Relationship between Packed Cell Volume and Infection Rate in Humbo District, Southern Ethiopia

Table5: Bonferroni multiple comparison test for identification of category with mean PCV difference

\begin{tabular}{|l|l|}
\hline Bonferroni multiple comparison test & P value \\
\hline Comparison categories & 0.000 \\
\hline Negative category and T. congolense positive category & 0.033 \\
\hline Negative category and T. vivax positive category & 1.000 \\
\hline$T$. congolense positive category and T. vivax positive category
\end{tabular}

PCV =Packed Cell Volume; $C I=$ Confidence Interval $; S D=$ Standard Deviation $; T=$ Trypanosoma

From the total of 306 examined animals, $83.98 \%$ (257/306) were anemic with mean PCV of $18.18 \%$ (95\% CI 16.67-18.68) while $16.02 \%$ (49/306) were non-anaemic and their mean PCV was 26.38 (95\% CI 25.95-26.8) (Table 6). The overall anaemia prevalence was found to be $83.98 \%$ (95\% CI 79.85-88.11). Comparison of trypanosomosis prevalence between anaemic and non-anaemic animals revealed that out of 257anaemic animals, $41 \quad(15.95 \%)$ were parasitaemic while, none $(0 \%)$ of non-anaemic animals are parasitaemic.

The proportion of parasitaemic animals among the anemic ones $(15.95 \%)$ was significantly

Table6: Comparison of trypanosomosis infection between anaemic and non-anaemic cattle

\begin{tabular}{|l|c|c|c|c|c|c|}
\hline \multicolumn{1}{|c|}{ Category } & $\begin{array}{c}\text { No } \\
\text { examined }\end{array}$ & $\begin{array}{c}\text { No of } \\
\text { positives }\end{array}$ & $\begin{array}{c}\text { Proportion of } \\
\text { Positives [95\% CI] }\end{array}$ & $\begin{array}{c}\text { Mean PCV [95\% } \\
\text { CI] }\end{array}$ & \multirow{\chi}{\boldsymbol{\chi}\text{[95}}{$\begin{array}{c}\text { P } \\
\text { value }\end{array}$} \\
\hline Anaemic & 257 & 41 & $15.95[11.44-20.46]$ & $18.18[16.67-18.68]$ & \multirow{2}{*}{9.02} & 0.003 \\
\hline Non-anaemic & 49 & 0 & $0[0-3.62]$ & $26.38[25.95-26.8]$ & & \\
\hline Overall & 306 & 41 & $13.4[9.8-17.7]$ & $19.52[18.97-20.07]$ & & \\
\hline
\end{tabular}

$P C V=$ Packed Cell Volume; $C I=$ Confidence Interval

Table7: Comparison of anaemia prevalence between parasitaemic and aparasitaemic cattle

\begin{tabular}{|c|c|c|c|c|c|c|c|}
\hline $\begin{array}{l}\text { Infection } \\
\text { status }\end{array}$ & $\begin{array}{l}\text { No } \\
\text { examined }\end{array}$ & $\mathrm{PCV} \leq 24$ & PCV>24 & № of anaemic & $\begin{array}{l}\text { Prevalence } \\
\text { ofanaemia }(\%)\end{array}$ & $\chi^{2}$ & $P$ value \\
\hline Parasitaemic & 41 & 41 & - & 41 & 100 & \multirow[t]{3}{*}{9.02} & \multirow[t]{3}{*}{0.003} \\
\hline Aparasitaemic & 265 & 216 & 49 & 216 & 81.5 & & \\
\hline Overall & 306 & 257 & 49 & 257 & 83.98 & & \\
\hline
\end{tabular}

PCV =Packed Cell Volume

\section{DiscuSSION}

During the present study, an overall trypanosomosis infection rate of $13.4 \%(95 \%$ $\mathrm{Cl}=9.8-17.7)$ resulted. The present finding was in line with results of Feyisa et al (2011), Degneh et al (2016), Yibrah and Simeamlak (2013), and Gemtessa, T and Dera KL (2017) which found an overall prevalence of $14.2 \%$ in Humbo distrct, $14.1 \%$ in Gidami distrct, $15.57 \%$ in Eastern Wollega, and $12.28 \%$ in Dale Wabera distrct, respectively. On the other hand, this finding was significantly lower than the reports of Zekarias and Zeryehun (2011), Belete (2017), Abera et al (2015), and Amare (1995) who reported $27.5 \%, 26.3 \%, 21.33 \%$, and $21.0 \%$ prevalence of bovine trypanosomosis respectively at Wozeka, Nyangatom woreda, Konta special distrct, and
$(\mathrm{P}<0.05)$ higher compared to the proportion of parasitaemic animals among the non-anemic ones $(0 \%)$ (Table6). Furthermore, comparison of anaemia prevalence between parasitaemic and aparasitaemic animals revealed that all parasitaemic animals (100\%) are anaemic; while among the 265aparasitaemic animals, 216 $(81.5 \%)$ were anaemic with PCV value $<25$. The proportion of anemic animals among the parasitaemic ones (100\%) was significantly higher compared to the proportion of anemic animals among the parasitemic ones $(81.5 \%)$ $(\mathrm{P}<0.05)($ Table7).
Omo river basin of South Western Ethiopia. The possible explanation for the lower report in the current study could be attributed to concerted efforts of tsetse suppression and trypanosomosis control by Arbam in chtsetse fly and trypanosomosis investigation and control center, disturbance of tsetse ecology due to bush clearing for expansion of cultivation area which could have significantly reduced tsetse population in the study area. However, this finding is only slightly lower than the recent finding in the same district by Feyisa et al (2011) which found $14.2 \%$ infection rate. The hypothesized reason for this is the availability of dense vegetation harboring tsetse flies in Bisare, Chokare and Gurucho PAs where cattle graze regularly thereby incurring tsetse fly bite. 
Out of 41 trypanosome positive animals, 37 (90.24\%) were found to be infected with $T$. congolense and the rest $4(9.76 \%)$ were infected with $T$. vivax. The higher proportion of $T$. congolense in the study area is in line with findings of Feyisa et al (2011), Biyazen et al (2014), Abera et al (2015) and Gona et al (2016). The predominance of $T$. congolense in the study area suggests that glassine species are more efficient transmitters of $T$. congolense than T. vivax in East Africa (Lang ridge, 1976) and also due to the high number of serodems of $T$. congolense as compared to T. vivax and the development of better immune response to $T$. vivax by infected animals (Rowlands et al., 1993).

The infection rate of trypanosomosis was higher in Gurucho PA (21.6\%) followed by Bisare PA $(20 \%)$ and Chokare PA (18.9\%) and there was a significant difference in trypanosomosis infection rate among PAs (study villages) $(\mathrm{p}<0.05)$. This result is in conformity with findings obtained by Getnet (2008) at SoddoZuria district, Feyisa et al (2011) in Humbo district, and Abera et al (2015) in Konta special district. The possible reason for the difference among PAs could be attributed to higher tsetse challenge in Gurucho and Bisareand Chokare PAs due to availability of dense bush land which serves as suitable pocket area for tsetse reproduction. However, no positive animals were found in Gafata PA and the prevalence of trypanosomosis was lower in Mareka PA in comparison to the other study PAs. This could be due to relatively lower vulnerability to tsetse fly challenge in these PAs in comparison to the other study PA due to sustainable tsetse and trypanosomosis suppression based on the rolling carpet principle and establishment of natural barrier with expansion of cultivation land in Mareka PA.

In the present study, trypanosomosis infection rate varied significantly $(\mathrm{p}<0.05)$ among different body condition categories with high prevalence recorded in animals with poor body condition $(24.5 \%)$. Animals with poor body condition score were more associated with disease compared to animals with medium and good body condition. This finding was similar with Habtwolde (1995), Dawud and Molalegne (2011) and Abiy (2002). Obviously, the disease itself results in progressive emaciation of the infected animals; nevertheless, non-infected animals under good body condition have well developed immune status that can respond to any foreign protein better than those of noninfected cattle with poor body condition score which can be immuno-compromised due to other diseases or malnutrition and concurrent infections depress the immune responsiveness in the same cases (Collins, 1994).

The infection rate of trypanosomosis was slightly higher in male animals $(14.4 \%)$ than the female ones $(12.7 \%)$ though it was not statistically significant $(p>0.05)$. Similar results have been reported by different works (Afework, 1998; Muturi, 1999; Tewolde, 2001; Mulugeta et al., 2013). The possible explanation for the present finding would be that male animals are more exposed to traction power and also cross different vegetation for grazing and watering where tsetse challenge is higher.

In the present study, age was considered to be one of the risk factors for trypanosome infection. Accordingly, higher infection rate (17\%) was observed in adult animals (>3yrs) than young animals $(\leq 3 \mathrm{yrs})(8.8 \%)$ in the study area. This result is in conformity with findings of Feyisa et al (2011), Yigzaw et al (2017), and Ayana et al (2012). There was statistically significant difference among different age groups $(\mathrm{P}<0.05)$. The possible reason for this is natural protection mounted by maternal antibodies which are abundant in young animals and depleted in the older counterparts (Fimmen et al, 1999).

The mean PCV of non-infected animals was $20.17 \pm 4.67 \mathrm{SD}$; that of $T$. congolense positive was $15.37 \pm 3.82 \mathrm{SD}$ where as $T$. vivax positive animals had mean PCV of 14.25 $\pm 6.13 \mathrm{SD}$. There was a significant difference in mean PCV between non-infected animals and $T$. congolense positive animals $(\mathrm{p}<0.05)$ as well as between non-infected animals and $T$. vivax positive animals $(\mathrm{p}<0.05)$. This indicates that though both parasitaemic and aparasitaemic animals are anaemic (with mean PCV <25\%), the mean PCV of parasitaemic animals was still lower than the aparasitaemic ones. This could be attributedto the fact that trypanosomosis predisposes infected animals to other concurrent infection due to immuno suppression (Radostitisetal., 2007) which in turn could have caused a lower mean PCV in infected animals compared to non-infected ones.

Out of the 306 examined animals, 257 were anaemic with over all anaemia prevalence of $83.98 \%$. This finding is higher than the previous 
studies by Haile et al (2016), Yigzaw et al (2017), Zecharias and Zeryhun(2012) which found $19.27 \%, 19.67 \%$, and $41 \%$ at Dale Wabera, Yayo and Arbaminch districts respectively. The mean PCV of parasitaemic and aparasitaemic animals was $14.4 \pm 4 \mathrm{SD}$ and $20.17 \pm 4.67 \mathrm{SD}$ respectively. There was a significant variation of mean PCV values between parasitaemic and aparasitaemic cattle $(\mathrm{p}<0.05)$. This result is in agreement with Rowlands et al. (1999) who observed that an increase in PCV value will result in decrease in proportions of positivity and hence mean PCV was a good indicator for the health status of animals in an endemic area.

This finding is in line with the results of Leak et al (1999), Afework (1998), Muturi (1999) and Tewolde (2001). Moreover, all (100\%) of parasitaemic animals are anaemicwhile $(81.5 \%)$ of aparasitaemic animals are anaemic. The proportion of anaemic animals among the parasitaemic ones (100\%) was significantly $(\mathrm{P}<0.05)$ higher than the proportion of anemic animals among the aparasitaemic ones $(81.5 \%)$.This finding conforms with previous studies by Zekarias and Zeryhun (2012) at Arbaminch (85\%), Degeneh et al (2017) at Gidami district ( $(92.3 \%$ in early dry and $91.3 \%$ in early rainy seasons). This suggests that anemia distribution was higher in infected cattle than in the non-infected ones. This is attributed to the fact that anaemia is useful indicator of trypanosomosis infection in endemic areas (Radostitis et al, 2007).Moreover, among the 257anaemic animals 41 (15.95\%) were parasitaemic while none $(0 \%)$ of non-anaemic animals are parasitaemic.

The proportion of parasitaemic animals among the anemic ones (15.95\%) was significantly higher compared to the proportion of parasitemic animals among the non-anemic ones $(0 \%)(\mathrm{P}<0.05)$. This finding further strengthens the fact that anaemia is characteristic of trypanosomosis infection. The result also showed that majority of aparasitaemic animals $216(81.5 \%)$ had PCV value $<25$. This suggests that although anaemia is characteristic of trypanosomosis, other concurrent infections are also anticipated to affect the PCV profile of animals. Diseases such as gastrointestinal parasitism, vector-borne diseases and nutritional deficiencies can also cause reduction in PCV (Van den Bossche and Rowlands, 2001).

\section{CONClusion}

In the present study, trypanosomosis infection rate in the study area is slightly lower than it is before due to implementation of tsetse fly and trypanosomosis control by Arbaminch Tsetse fly and trypanosomosis investigation and control center. However, the current trypanosmosis infection rateis still significant to the level that it hinders cattle production in Humbo district.The prevailing trypanosome species in the study area were T. congolense and T.vivax with predominance of $T$. congolense. The study revealed that peasant associaton (PA), body condition andage of animals were found to be potential risk factors for trypanosomosis infection. Anemia was characteristic of trypanosomosis infection in the area. Therefore, further integrated control approaches particularly application of ground suppression and deployment of insecticide impregnated targets on tsetse pocket areas, application of adequate pour-on insecticide on vulnerable cattle needs to be implemented to significantly lower the infection rate. Moreover, further season-based studies should be conducted to determine apparent density of tsetse flies and to observe seasonal dynamics of trypanosomosis infection in the area.

\section{ACKNOWLEDGEMENT}

We would like to acknowledge Arbaminch Tsetse and Trypanosomosis Investigation and Control Center for material support.

\section{REFERENCES}

[1] Abebe G, Jobre Y. Trypanosomosis: a threat to cattle production in Ethiopia. Rev Med Vet. 1996; 147:897-902.

[2] Abebe G. Current situation of Trypanosomosis, In: review article on: Trypanosomosis in Ethiopia. Ethiop. J. Biol. Sci. 2005:4:75-121.

[3] Abera A, Sibhat B, Tonamo A. A study on the prevalence of bovine trypanosomosis in selected areas of Konta Special Woreda, Southern Ethiopia. Journal of Agricultural Research. 2015: 11(6) 500-506.

[4] Abiy M. Prevalence of bovine trypanosomosis in Goro woreda, southwest Ethiopia. DVM Thesis FVM, AAU, Debrezeit, Ethiopia. 2002; Pp 18.

[5] Afework Y. Field investigations on the appearance of drug resistant population of trypanosome in Metekel district, Northwest Ethiopia. Msc Thesis, AAU with Frey University, Berlin.1998.

[6] Asfaww. Tsetse and trypanosomosis survey in Bunno province. AAU, Faculty of Veterinary Medicine, Debre Zeit, DVM thesis. 1986. 
[7] Ayana M, Tesfaheywet Z, Getnet F. A crosssectional study on the prevalence of bovine trypanosomosis in Amhara region, Northwest Ethiopia. Journal Livestock Research for Rural Development: 2012; 24(8).

[8] Belete D.A. Across-sectional study on the occurrence of bovine trypanosomosis and its risk factors in Nyangatom woreda, Southern Ethiopia. Global Journal of Veterinary Medicine and Research. 2017; 5(7): 148-152.

[9] Biyazen H, Duguma R, Asaye M. Trypanosomosis: Its risk factors and anaemia in cattle population of Dale Wabera district of Kelem Wolega Zone, Western Ethiopia. J.Vet Med: 2014: 374191.

[10] Collins FM. The immune response to mycobacterium infection, development of new vaccine. Vet. Microbiol. 1994; 40:95-110

[11] CSA (Central Statistical Agency). Agricultural sample survey, volume II: report on livestock and livestock characteristics (Private peasant holdings). Statistical bulletin 570. Addis Ababa: Federal Democratic Republic of Ethiopia; 2013.

[12] Dawud A and MolalegnB. Epidemiological study of Bovine Trypanosmosis in Mao-komo Special District, Benishangul Gumuz Regional State, Western Ethiopia. Global Veterinaria, 2011; 6: 402-408.

[13] D 'Teteren G. D. M, Authie E, Wissoqeo N, MurryM. Trypanotolerance an option for susitainable livestock production in areas at risk from trypanosomosis OIE scientific and Technical review. 1998; Pp 154-175.

[14] Fimmen H.O, Mehlitz D, Horchiner FandKorb E. Colostral antibodies and Trypanosome congolese infection in calves. Trypanotolerance research and application GTZ, Germany. 1999; No116: 173-178

[15] Abebe G. Trypanosomosis in Ethiopia. Ethiop J Biol Sci. 2005; 4:75-121.

[16] Gemtessa T and Dera KL. Study on prevalence of trypanosomosis in Dale Wabera district, Kellam Wollega Zone, Western Ethiopia. Int J Anim Sci. 2017;1(1):1002

[17] Getachew A. Review Article Trypanosomosis in Ethiopia. Acad J Ani Dis. 2005; 1(1):11-15.

[18] Getnet B. Prevalence of bovine trypanosomosis in SoddoZuriaWereda, SNNPRS. DVM thesis. Haramaya University, Ethiopia, 2008.

[19] Gona Z, Teshale A, Tilahun A. Study on prevalence of bovine trypanosomosis and density of its vectors in three selected districts of Wolaita Zone, Southern Ethiopia. J. Vet. Med. Anim. Health. 2016; 8(9): 128-135.

[20] Habtwolde T. Community based tsetse and trypanosomosis control pilot programme using Deltamethrin in Konso, Southern Ethiopia.
Proceeding of 11th Conference of the Ethiopia Veterinary Association, Addis Ababa, Ethiopia; 1995; pp. 57-65.

[21] Haile C. Bovine trypanoso- mosis in North Oromo, prevalence and assessment of drug efficacy DVM Thesis Addis Ababa University, Debre Zeit, Ethiopia; 1996.

[22] Haile G, Mekonnen N, Lelisa K, Habtamu Y. Vector identification, prevalence and anemia of bovine trypanosomosis in Yayo District, Illubabor Zoneof Oromia Regional State, Ethiopia. Ethiopian Veterinary Journal 2016; 20(1):39-54.

[23] ILRAD. Annual report, Nairobi, Kenya; 1993/ 94.

[24] Itard J. African animal trypanosomosis. In manual of veterinary Parasitology. 1981; Pp. 179-291.

[25] Jordan A.M. Trypanosomosis control and Africa Rural Development, New York: Longman group; 1986.

[26] Langridge W.P. A tsetse and trypanosomosis survey of Ethiopia. Ministry of overseas Development, UK and Ministry of Agriculture of Ethiopia.1976; Pp 1-98.

[27] Leak SGA. Tsetse Biology and Ecology: Their role in the Epidemiology and control of Trypanosomosis. Wallingford, Oxon, UK: CABI publishing. 1999; Pp. 152-210

[28] Mc Lennan K.J.R. Tsetse transmitted Trypanosomosis in relation to rural economy in Africa. Part I. Tsetse infestation, World Animal Rev. 1980; 37, 9-18.

[29] MoA. Annual report of trypanosomosis control service. Addis Ababa, Ethioipia; 1982/823.

[30] Muturi KS. Epidemiology of Bovine Trypanosomosis in selected sites of the Southern Rift Valley of Ethiopia. MSc Thesis, FVM, AAU, Ethiopia; 1999.

[31] Nantulya, V.M. Immunological approaches to the control of animal Trypanosomosis: Trop. Med parasite.1986; 140:168-173.

[32] Nicholson MJ and Butterworth MH. A guide to body condition scoring of zebu cattle. ILCA, Addis Ababa Ethiopia. 1986; pp. 212-235.

[33] Radostitis, O.M., Gay, C.C., Blood, D.C. and Hinchcliff, K. W. Veterinary medicine. A text book of the disease of Cattle, Sheep, Pigs, Goats and Horses.10th ed. W.B.Saunders Ltd. 2007; Pp 1395-1412.

[34] Rowlands GJ, Mulatu W, Authie E, Leak S.G.A,D'iteren GD, Naga SM, Peregrine AS. Epidemiology of bovine trypanosomosis in the Ghibe valley, southwest Ethiopia. 2. Factors associated with variations in trypanosome prevalence, incidence of new infections and prevalence of recurrent infections. Acta Trop. 1993; Apr; 53(2):135-50. 
[35] Rowlands G.M, Woudyalew M, Authie E.J.D, Iteren G.D.M, Leak S.G.A, Nagda S.M, Peregrine A.S, and Mariega J. M.A method for distinguishing new and recurrent trypanosome infections in a field survey of East Africa zebu cattle in Ethiopia; 1993.

[36] Rowlands GS, Mulatu W, Authie E, Leak SGA, Peregrine A. Epidemiology of bovine Trypanosomosis in the Ghibe valley, South West Ethiopia. Acta Trop. 1999; 53:135-150.

[37] Paris J, Murray M., and Mcodimba F. A Comparative evaluation of the parasitological technique currently available for the diagnosis of African Trypanosomosis in Cattle, Acta Trop.1982; 39: 307-316.

[38] STEP. Ministry of Science and Technology. Southern tsetse eradication project (step). Field operation manual of tsetse and trypanosomosis control and monitoring, Addis Ababa, Ethiopia, 2012:5-63

[39] Teka W, Terefe D, Wondimu A. Prevalence study of bovine trypanosomosis and tsetse density in selected villages of Arbaminch, Ethiopia. J. Vet. Med. Anim. Health 2012; 4(3):36-41.

[40] [40] Tewolde N. Study on the occurrence of resistant trypanosomes in cattle in the farming in tsetse control areas (FITCA) project in western Ethiopia MSc thesis, Addis Ababa University and Freie Universtat, Berlin; 2001.

[41] Thrus field, M. Veterinary epidemiology. 3rd ed. Black well science Ltd., Oxford, Great Britain. 2005; Pp. 182-198.

[42] Van den Bossche P and Connor RJ. African Animal Trypanosomosis; in infectious disease of livestock. Oxford University Press, Cape town, 2004; 12: 253

[43] Van den Bossche P and RowlandsG.J. The relationship between the parasitological prevalence of trypanosome infections in cattle and herd average packed cell volume. Acta Tropica. 2001; 78(2):163-170.

[44] WZSEP. Wolaita Zone Socio-economic Profile. WolaitaSoddo, Ethiopia; 2010.

[45] Yibrah $\mathrm{T}$ and Simeamlak M. Prevalence of bovine trypanosomosis in Tsetse Controlled and Uncontrolled Areas of Eastern Wollega, Ethiopia. 2013:2(1).

[46] Yigzaw B, AsmareT, Dereso S. Prevalence of bovine trypanosomosis and its vector density in in Sheka Zone, Andericha woreda. Online Journal of animal and feed research 2017; 7(3): 51-57.

[47] Zecharias, A and Zeryehun, T. Prevalence of bovine trypanosomosis in selected district of Arba Minch, SNNPR, Southern Ethiopia. Global Veterinaria. 2012; 8(2), 168-173.

Citation: Ephrem Takele, et al. Bovine Trypanosomosis: Infection Rate, its Risk Factors, and the Relationship between Packed Cell Volume and Infection Rate in Humbo District, Southern Ethiopia, ARC Journal of Animal and Veterinary Sciences. 2020; 6(1):1-10. doi: dx.doi.org/10.20431/2455-2518.0602001.

Copyright: (C) 2020 Authors. This is an open-access article distributed under the terms of the Creative Commons Attribution License, which permits unrestricted use, distribution, and reproduction in any medium, provided the original author and source are credited. 